\title{
Peningkatan Entrepreunership Melalui Inisiasi dan Pelatihan Pengemasan Wedang Pucuk Daun Jati (Tectona Grandis L.F)
}

\author{
Suwahono \& Sri Mulyanti \\ Universitas Islam Negeri Walisongo Semarang \\ Email: suwahono@walisongo.ac.id
}

\begin{abstract}
The entrepreneurial spirit and value can be influenced through the initiation process, and business training. pharmacological analysis of teak shoots (Tectona Grandis 1.f) had antibacterial, antioxidant, antifungal, antiinflammatory, antipyretic, analgesic, anti-diuretic, and hypoglycemic activity. The use of teak leaves in the form of easy use should be disseminated and introduced through initiation and entrepreneurship training. The results of this studied indicate had a significant influence between initiation and training of teak leaf packaging with the entrepreneurial spirit and value. Entrepreneurship training can provide a good / positive contribution to the implementation of the business of students participating in the training because it helps in solving the obstacles that have been whacking business students..
\end{abstract}

Abstrak: Semangat dan nilai kewirausahaan dapat dipengaruhi melalui proses inisiasi, dan pelatihan bisnis. Analisis farmakologis tunas jati (Tectona Grandis 1.f) memiliki aktivitas antibakteri, antioksidan, antijamur, antiinflamasi, antipiretik, analgesik, anti diuretik, dan hipoglikemik. Penggunaan daun jati dalam bentuk mudah digunakan harus disebarluaskan dan diperkenalkan melalui pelatihan inisiasi dan kewirausahaan. Hasil penelitian ini menunjukkan bahwa pelatihan memiliki pengaruh yang signifikan antara inisiasi dan pelatihan pengemasan daun jati dengan semangat dan nilai wirausaha. Pelatihan kewirausahaan dapat memberikan kontribusi yang baik / positif untuk pelaksanaan bisnis siswa yang berpartisipasi dalam pelatihan karena membantu dalam memecahkan hambatan yang telah memukul siswa bisnis.

Kata Kunci: wirausaha, pelatihan, wedang pucuk daun jati. 


\section{PENDAHULUAN}

Dunia pendidikan saat ini harus mampu berperan aktif menyiapkan sumber daya manusia (SDM) terdidik guna menghadapi tantangan kehidupan baik lokal, regional, nasional maupun internasional. SDM tidak cukup hanya menguasai teori-teori, namun dituntut memiliki kecakapan dalam menerapkan ilmunya dalam masyarakat. Teori yang diberikan tidak akan ada artinya jika tidak diiringi dengan pengenalan pelatihan dan praktek langsung. Proses tersebut ini harus dilakukan di bawah pantauan pelatih,agar terbentuk wirausaha produktif yang cermat membaca pasar. Pelatihan ini dilakukan untuk merangsang tumbuhnya jiwa wirausaha.

Perguruan tinggi berperan strategis dalam peningkatan daya saing bangsa. Daya saing menjadi kunci kemenangan di Era Masyarakat Ekonomi Asian. Era persaingan sudah di depan mata, karena itu perkuliahan harus lebih cepat meningkatkan mutu SDM sesuai kebutuhan. Hal ini berbanding terbalik dengan Data Badan Pusat Statistik (BPS) menyatakan, jumlah lulusan perguruan tinggi yang bekerja adalah 12,24 persen. Jumlah tersebut setara 14,57 juta dari 118,41 juta pekerja di seluruh Indonesia. Sementara pengagguran lulusan perguruan tinggi mencapai 11,19 persen, atau setara 787 ribu dari total 7,03 orang yang tidak memiliki pekerjaan.

Bagi para mahasiswa, menjadi entrepreneur sangatlah penting, dengan menjadi wirausaha, otomatis lapangan kerja akan semakin bertambah. Terbukanya lapangan kerja, maka angka pengangguran terutama mahasiswa yang lulus Perguruan Tinggi akan turun dan lulusan perguruan tinggi tidak hanya mencari pekerjaan tetapi bisa menciptakan lapangan pekerjaan. Proses mengembangkan jiwa kewirausahaan dikalangan mahasiswa merupakan salah satu metode yang paling efektif untuk menyiapkan jiwa kewirausahaan mahasiswa(Timmons \& Spinelli, 2004: 31). Saat ini kewirausahaan di perguruan tinggi sudah merupakan pembelajaran yang sudah diformalkan dan telah melembaga. Banyak model strategi dan pendekatan yang digunakan untuk meningkatkan jiwa wirausaha mahasiswa. Hasil penelitian pendahuluan menyatakan bahwa Model dan strategi yang diterapkan masih berbasis teori dan miskin praktik. Bekal kewirausahaan mahasiswa harusnya dapat terbangun semangat survival dan itu bisa dimulai dari inisiasi dan pelatihan.

Berdasarkan kenyataan tersebut, maka pola pembelajaran kewirausahaan di Perguruan Tinggi saat ini perlu diubah berdasarkan kompetensi, yaitumelatih mahasiswa secara fisik dan mental melalui pembiasaan dalam kehidupan seharihari sehingga akan menjadi tangguh untuk mengambil keputusan dan memecahkan masalah. Hal inilah yang menjadi dasar penting penelitian ini untuk 
mengupayakan peningkatan jiwa kewirausahaan mahasiswa melalui inisiasi dan pelatihan wedang pucuk daun jati (tectona Grandis l.f)

\section{KAJIAN WEDANG PUCUK DAUN JATI}

Pola kebiasaan hidup manusia sekarang ini cenderung terpapar pada berbagai polusi(cemaran) baik dari udara, air maupun makanan, yang dapat meningkatkan radikalbebas (racun dalam tubuh). Akumulasi paparan kimia ini dalam tubuh bila dibiarkan akanmenurunkan imunitas dan stamina serta meningkatkan risiko timbulnya berbagaipenyakit serta dapat menyebabkan obesitas (Gholap \& Kar, 2005).

Tren pencegahan dan pengobatan penyakit saat ini adalahmengggunakan bahan alami. Wedangan merupakan salah satubudaya masyarakat Indonesia. Wedangan dijadikan minuman yang bukan hanyamenyegarkan, namun juga menyehatkan karena mengandung zat catehchin sertaantioxidan lainnya. Daun jati merupakan salah satu jenis daun dengan ukuran yang cukup lebar untuk sebuah daun. Selama ini kita mengenal pohon jati sebagai pohon yang memiliki kualitas terbaik untuk dijadikan bahan dalam bangunan rumah atau perabotan rumah. Kegunaan daun jati di masyarakat Jawa biasanya dibuat sebagai daun pembungkus makanan karena jenis daunnya yang tebal dan lebar. Selain itu, daun ini juga akan memberikan wangi harum yang khas pada makanan yang dibungkusnya. Manfaat lain yang jarang diketahui orang adalah sebagai pengobatan terhadap gangguan lipid, radang, maag, bronkitis, anti hipertensi, anti diabetes dan anti infeksi saluran kencing (Warrier,1994), antiulcer (Pandey et al., 1982), antimicrobial (Sumthong et al., 2006), obat luka dan obat diet (Majumdar et al., 2007), dan aktivitas anti kangker (Khan \& Miungwana, 1999). Pucuk daun jati mengandung saponin, tanin, kuinon, flavonoid, dan juga beberapa zat lainnya yang berfungsi untuk menyehatkan tubuh.

Jika ditinjau dari sisi akademis perlunya penyebaran kepada masyarakat hasil penelitian diperguruan tinggi tidak hanya menjadi data diperpustakaan tetapi dapat dimanfaatkan oleh masyarakat awam. Dari wirausaha dari aspek pemasaran, wedang pucuk daun jati memberikan suatu prospek bisnis yang menguntungkan. Hanya masyarakat dari golongan tertentu saja yang telah mengetahui dan mengenal keberadaan dan khasiat dari wedang pucuk daun jati. Bahkan dari kalangan akademisi (mahasiswa, dosen) di Indonesia masih banyak yang belum mengenal khasiat wedang pucuk daun jati ini. Masyarakat modern butuh inovasi dan kepraktisan dalam pemanfaatan. 
Berdasarkan pikiran tersebut perlu adanya upaya memadukan upaya peningkatan jiwa kewirausahaan dengan memulai bisnis pengembangan produk yang inovatif dan pemasaran wedang pucuk daun jati. Hal inilah yang menjadi alasan perlunya inisiasi inovasi membuat dan memasarkan wedang pucuk daun jati dalam bentuk minuman kemasan siap saji, sehingga konsumen dengan mudah memperoleh dan menikmatinya sekaligus dapat memperoleh khasiatnya

\section{METODE PENELITIAN}

Metode yang untuk digunakan dalam penelitian ini adalah metode deskriptif. Menurut Moleong, (1999) metode deskriptif adalah sebagai "prosedur pemecahan masalah yang diselidiki dengan menggambarkan atau melukiskan keadaan subyek atau obyek penelitian (seseorang, lembaga, masyarakat, dan lainlain) pada saat sekarang berdasarkan fakta-fakta yang tampak sebagaimana adanya". Bentuk penelitian yang digunakan dan dianggap sesuai dalam penelitian ini yaitu penelitian studi kasus yang bertujuan untuk mencari fakta atau gejalagejala mengenai "Dampak positif inisiasi pelatihan pengemasan wedang pucuk daun jati dalam meningkatkan jiwa kewirausahaan mahasiswa ilmu gizi UIN walisongo.

Sumber data primer dalam penelitian ini adalah peneliti dan informan yang terdiri atas 20 mahasiswa ilmu gizi yang sudah mengikuti pelatihan kewirausahaan. Sumber data sekunder dalam penelitian ini adalah data yang berupa arsip-arsip dan data-data yang dimiliki peneliti dan data yang berkaitan dengan pelatihan kewirausahaan, seperti data dokumenter-dokumenter pelatihan kewirausahaan.

Teknik pengumpulan data yang digunakan dalam penelitian ini adalah: (1) Teknik observasi langsung. Observasi langsung dilakukan melalui satu pengamatan dan mencatat gejala-gejala yang tampak pada objek yang hendak diteliti dengan melihat dimana tempat, keadaan serta situasi yang sedang terjadi. (2) Teknik komunikasi langsung. Yaitu mengumpulkan data dengan melakukan hubungan langsung, dengancara mengajukan pertanyaan-pertanyaan kepada informan yang sudah mengikuti pelatihan kewirausahaan. (3) Teknik studi documenter dengan cara mengumpulkan data dengan menggunakan literaturliteratur maupun arsip atau dokmen-dokumen yang ada dan klasifikasi bahan tertulis yang berhubungan dengan masalah penelitian.

Data yang sudah terkumpul selanjutnya dianalisis.Data hasil penelitian diolah menggunakan rumus persentase (\%). Ada pun rumus presentase adalah sebagai berikut: $\mathrm{P}=\mathrm{p} / \mathrm{f} \times 100 \%$. Ada 4 fase mengevaluasi suatu pelatihan, yang tampak pada gambar 1 . 


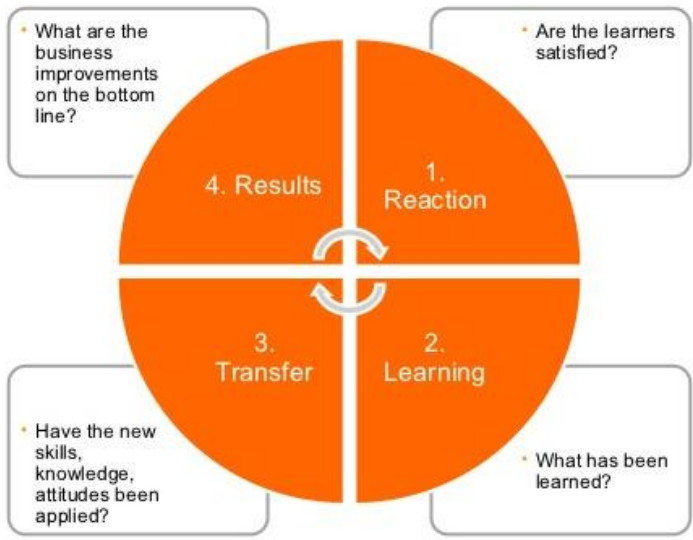

Gambar 14 Fase evaluasi pelatihan

(Roger Buckley and Jim Caple, The Theory and Practice of Training (Kogan Page, 1995)

Penjelasan dari gambar 1 bisa dijelaskan sebagai berikut; a) Reaction (Reaksi), Pada fase ini, evaluasi ingin mengukur apakah peserta pelatihan menyukai program, pelatihan, dan fasilitas pelatihan; b) Learning (Pembelajaran), Pada fase ini dilakukan evaluasi seberapa jauh peserta pelatihan mempunyai keterampilan dan pengetahuan lebih tinggi dari sebelumnya, setelah mengikuti program pelatihan; c) Transfer (transfer), Pada fase ini dilakukan evaluasi apakah peserta pelatihan mersa mendapat transfer ilmu setelah pelatihan; dan d) Result (Hasil), Pada tingkat ini dilakukan evaluasi tentang evaluasi hasil pelatihan.

\section{HASIL DAN PEMBAHASAN}

Hasil penelitian diolah berdasarkan metodologi yang diacu meliputi empat fase pelatihan. Pertama, Reaction (Reaksi). Informan sekaligus peserta pelatihan yang mengikuti pelatihan kewirausahaan berjumlah 4 orang laki-laki $20 \%$ dan 16 orang atau $75 \%$ orang perempuan.Hasil tanggapan pelaksanaan kewirausahan oleh peserta pelatihan secara presentasi ditampilkan pada tabel 1.

Berdasarkan tabel. 2 diatas, dapat dijelaskan bahwa sebanyak $50 \%$ (10 responden) menjawab bahwa pelaksanaan pelatihan kewirausahaan sangat baik, $25 \%$ (5 responden) menjawab bahwa pelaksanaan pelatihan kewirausahaan cukup baik, $25 \%$ (5 responden) menjawab pelaksanaan pelatihan kewirausahaan cukup baik. Melihat jawaban responden maka pelaksanaan pelatihan kewirausahaan dikategorikan baik karena sebanyak 50 \% (10 responden) menyatakan sangat baik karena materi pelatihan sesuai dengan kebutuhan santri 
mahasiswa sebagai calon pekerja, fasilitas yang memadai, ruang yang digunakan untuk pelatihan yang sangat mendukung serta pemateri pelatihan yang sangat baik dan berkompetensi dalam menyampaikan materi kewirausahaan sehingga hal inilah yang membuat pelaksanaan pelatihan ini dikatakan sangat baik.

Tabel.1 Respon informan terhadap pelaksanaan pelatihan kewirausahaan yang diselenggarakan

\begin{tabular}{clcc}
\hline \hline & Altenatif & Jawaban responden & Persentase (\%) \\
\hline \hline a. & Sangat Baik & 10 & $50 \%$ \\
\hline b. & Baik & 5 & $25 \%$ \\
\hline c. & cukup Baik & 5 & $25 \%$ \\
\hline & Jumlah & 20 & $100 \%$ \\
\hline
\end{tabular}

Sumber data Hasil pelatihan

Kedua, Learning (Pembelajaran). Berdasarkan sajian data tabel. 2, dapat dijelaskan bahwa 100\% (20 responden) menyatakan bahwa setelah mengikuti pelatihan kewirausahaan yang diselenggarakan peneliti peserta menyatakan bahwa pelatihan tersebut memberikan suatu manfaat yang baik bagi inisiasi usaha mereka, dan tidak ada responden yang menyatakan setelah mengikuti pelatihan kewirausahaan pelatihan tersebut tidak memberikan manfaat bagi mereka. Jadi, melihat dari jawaban responden maka dapat dikategorikan bahwa pelatihan kewirausahaan yang diikuti oleh peserta pelatihan.100\% (20 responden) menyatakan bahwa pelatihan memberikan manfaat yang positif atau baik karena mereka merasa mendapatkan wawasan pengetahuan tentang berwirausaha sehingga peserta pelatihan merasa paham dan tahu cara berwirausaha yang baik, dan cara/ kiat-kiat memanajemen/ mengelola usahan mereka dengan baik.

Tabel. 2. Setelah mengikuti pelatihan kewirausahaan, apakah pelatihan itu memberikan manfaat terhadap diri anda

\begin{tabular}{|c|c|c|}
\hline Altenatif & jawaban responden & Persentase $\mathbf{( \% )}$ \\
\hline a. Memberikan manfaat & 20 & $100 \%$ \\
\hline b. Tidak memberikan manfaat & & \\
\hline Jumlah & 20 & $100 \%$ \\
\hline
\end{tabular}

Sumber data Hasil pelatihan

Dari tabel. 3 diatas dapat dijelaskan bahwa 100\% (20 responden) menyatakan bahwa setelah mereka mengikuti pelatihan kewirausahaan mereka mengalami kemudahan dalam merumuskan rencana usaha mereka. Sedangkan 0\% (0 responden) menyatakan tidak ada perbedaan dalam perencanaan usaha mereka sebelum dan setelah mereka mengikuti pelatihan kewirausahaan.Jadi 
secara keseluruhan mahasiswa menyatakan bahwa ada perbedaan dalam perencanaan usaha mereka setelah mereka mengikuti pelatihan kewirausahaan.

Tabel. 3 Menurut anda, apakah ada perbedaan dalam pembuatan rencana usaha sebelum dan setelah anda mengikuti pelatihan kewirausahaan

\begin{tabular}{|c|c|c|}
\hline Altenatif & Jawaban Responden & Persentase $(\%)$ \\
\hline $\begin{array}{l}\text { a. Ada perbedaan, yaitu setelah } \\
\text { mengikuti pelatihan kewirausahaan } \\
\text { saya mengalami kemudahan dalam } \\
\text { merumuskan rencana usaha dan } \\
\text { paham cara memanajemen usaha } \\
\text { yang baik }\end{array}$ & 20 & 100 \\
\hline \multicolumn{3}{|l|}{$\begin{array}{l}\text { b. Tidak ada perbedaan melakukan } \\
\text { perencanaan usaha sebelum dan } \\
\text { setelah mengikuti pelatihan } \\
\text { kewirausahaan }\end{array}$} \\
\hline Jumlah & 20 & $100 \%$ \\
\hline
\end{tabular}

Sumber data Hasil pelatihan

Dari tabel.4 dapat dijelaskan bahwa 75\% (15 responden) menyatakan bahwa materi kewirausahaan yang mereka terima saat pelatihan sangat membantu mereka dalam merumuskan perencanaan usaha mereka.Sedangkan $25 \%$ (5 Rresponden) menyatakan bahwa materi kewirausahaan yang mereka terima saat pelatihan kewirausahaan sedikit membantu mereka dalam merumuskan perencanaan usaha yang mereka jalankan. Jadi secara keseluruhan atau $75 \%$ (15 responden) mahasiswa merasa materi kewirausahaan yang telah mereka dapatkan membantu mereka dalam merumuskan perencanaan usaha mereka tersebut.

Tabel. 4 Apakah materi pelatihan kewirausahaan yang di dapatkan pada saat pelatihan membantu dalam merumuskan perencanaan usaha yang anda jalankan?

\begin{tabular}{llcc}
\hline \hline \multicolumn{1}{c}{ Altenatif } & Jawaban Responden & Persentase (\%) \\
\hline \hline 1. & $\begin{array}{l}\text { Sangat membatu dalam } \\
\text { merumuskan perencanaan } \\
\text { usaha }\end{array}$ & 15 & $75 \%$ \\
\hline 2. & $\begin{array}{l}\text { Sedikit membantu dalam } \\
\text { merumuskan perencanaan } \\
\text { usaha }\end{array}$ & 5 & 25 \\
\hline 3. & $\begin{array}{l}\text { Tidak membatu dalam } \\
\text { merumuskan perencanaan } \\
\text { usaha }\end{array}$ & & \\
\hline Jumlah & 20 & $100 \%$ \\
\hline
\end{tabular}

Sumber data Hasil pelatihan 
Ketiga, Transfer (Transfer). Dari Tabel 5 diatas dapat dijelaskan bahwa 75 $\%$ (15 responden) menyatakan bahwa setelah mereka mengikuti pelatihan kewirausahaan mereka menganggap pelatihan kewirausahaan yang telah mereka ikuti sangat memberikan gambaran dalam menentukan organisasi usaha yang mereka jalankan. Sedangkan $0 \%$ menyatakan bahwa sebelum dan setelah mengikuti pelatihan kewirausahaan mereka menganggap sama saja materi yang didapatkan kurang memberikan gambaran dalam menentukan organisasi usaha mereka. Jadi secara keseluruhan atau 75\% (15 responden) menganggap setelah mereka mengikuti pelatihan kewirausahaan, mereka menganggap atau merasa materi yang mereka terima memberikan gambaran dalam menentukan organisasi usaha mereka karena pada dasarnya pelatihan kewirausahaan yang diselenggarakan membahas juga bagaimana menentukan organisasi usaha yang dijalankan.

Tabel.5 Apakah sebelum atau setelah mengikuti pelatihan kewirausahaan yang anda anggap lebih memberikan gambaran dalam menentukan organisasi usaha

\begin{tabular}{llcc}
\hline \hline \multicolumn{1}{c}{ Altenatif } & jawaban responden & Persentase (\%) \\
\hline \hline 1. & $\begin{array}{l}\text { Sebelum mengikuti pelatihan } \\
\text { kewirausahaan }\end{array}$ & 5 & $25 \%$ \\
\hline 2. & $\begin{array}{l}\text { Setelah mengikuti pelatihan } \\
\text { kewirausahaan }\end{array}$ & 15 & $75 \%$ \\
\hline 3. & $\begin{array}{l}\text { Sama saja, sebelum dan setelah } \\
\text { pelatihan kurang memberikan } \\
\text { gambaran dalam menentukan } \\
\text { organisasi usaha }\end{array}$ & \\
\hline \multicolumn{1}{c}{ Jumlah } & 20 & $100 \%$ \\
\hline
\end{tabular}

Keempat, Result (Hasil). Dari tabel 6 dapat dijelaskan bahwa $100 \%$ (20 responden) menyatakan bahwa materi kewirausahaan yang telah mereka dapatkan pada saat pelatihan kewirausahaan ternyata memberikan kontribusi yang baik pada saat mereka melakukan kegiatan usaha. Kontribusi positif yang dimaksud adalah melalui pelatihan tersebut membawa dampak yang baik bagi mahasiswa seperti: Mahasiswa merasa paham mengelola usahanya, Cara memanajemen usaha yang baik, merencanakan usaha yang baik, materinya memberikan gambaran bagi mahasiswa cara membuat organisasi yang baik dan benar, merencanakkan usaha yang baik serta materinya mengajarkan cara mengevaluasi usaha.

$0 \%$ (0 responden) menyatakan bahwa materi kewirausahaan yang dia dapatkan pada saat pelatihan kewirausahaan ternyata kurang memberikan kontribusi terhadap kegiatan usah yang dia jalankan karena mungkin antara 
materi yang sudah didapatkan dan bidang usaha yang dijalankan tidak ada kecocokkan sehingga materi pelatihan kewirausahaan kurang memberikan kontribusi dan tidak ada responden yang menjawab bahwa materi yang diterima tidak memberikan kontribusi terhadap kegiatan usaha mereka. Jadi secara keseluruhan materi kewirausahaan yang responden terima ternyata memberikan kontribusi yang baik terhadap kegiatan calon usaha mereka.

Tabel.6 Apakah materi pelatihan kewirausahaan yang diperoleh memberikan kontribusi pada saat anda melakukan kegiatan usaha Altenatif jawaban responden Responden

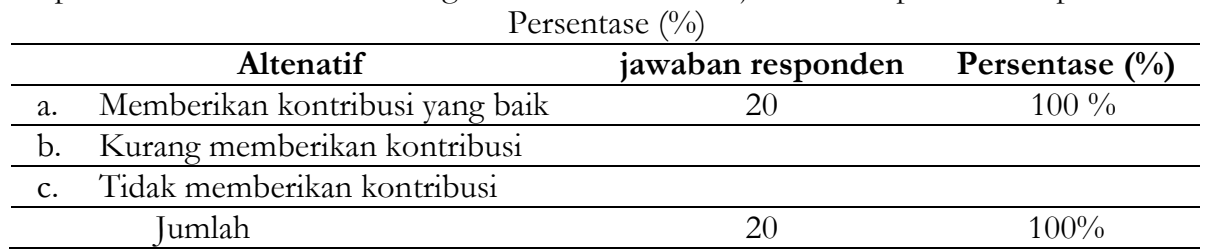

Sumber data Hasil pelatihan

Tabel.7 Dari kegiatan evaluasi usaha, apakah usaha pengemasan wedang pucuk daun jati layak atau tidak untuk dikembangkan kedepannya

\begin{tabular}{|c|c|c|}
\hline Altenatif & jawaban responden & Persentase $(\%)$ \\
\hline a. Layak dikembangkan & 19 & $95 \%$ \\
\hline b. Kurang layak untuk dikembangkan & 1 & $5 \%$ \\
\hline \multicolumn{3}{|l|}{ c. Tidak layak untuk dikembangkan } \\
\hline Jumlah & 20 & $100 \%$ \\
\hline
\end{tabular}

Sumber data Hasil pelatihan

Dari tabel. 7 diatas dapat dijelaskan $95 \%$ (19 responden) menyata bahwa setelah mereka melakukan evaluasi terhadap pelatihan usaha mereka ternyata mereka masih menganggap usaha pengemasan teh kelor layak untuk dikembangkan kedepannya. Sedangkan $5 \%$ (1 responden) menyatakan bahwa setelah melakukan evaluasi usaha pengemasan teh kelor kurang layak untuk dikembangkan dan tidak ada responden yang menjawab bahwa usaha yang dijalankan tidak layak untuk dikembangkan. Jadi secara keseluruhan usaha yang dijalankan layak untuk dikembangkan.

Secara keseluruhan inisiasi dan pelatihan yang telah didapatkan oleh informan pada saat pelatihan kewirausahaan berdampak positif terhadap calon usaha mahasiswa. Terdapat peningkatan minat usaha mahasiswa mengikuti pelatihan kewirausahaan. Berdasarkan hasil wawancara yang telah dilakukan mahasiswa merasa paham mengelola usahanya, cara memanajemen usaha yang baik,merencanakan usaha yang baik, materinya memberikan gambaran bagi mahasiswa cara membuat organisasi yang baik dan benar, merencanakan usaha 
yang baik serta materinya mengajarkan cara mengevaluasi usaha. Meskipun demikian terdapat 1 informan yang menyatakan bahwa materi kewirausahaan yang dia dapatkan pada saat pelatihan kewirausahaan ternyata kurang memberikan kontribusi terhadap kegiatan usahayang dia jalankan karena mungkin antara materi yang sudah didapatkan dan calon bidang usaha yang dijalankan mahasiswa tidak ada kecocokkan sehingga materi pelatihan kewirausahaan kurang memberikan kontribusi kontribusi terhadap kegiatan usaha mereka. Jadi secara keseluruhan materi kewirausahaan yang responden terima ternyata memberikan kontribusi yang baik terhadap kegiatan usaha mereka. Secara garis besar informan/mahasiswa selaku peserta pelatihan mendapatkan memberikan kontribusi yang besar dalam merumuskan perencanaan usaha yang baik. Pengorganisasian calon usaha mahasiswa setelah mengikuti pelatihan kewirausahaan terdapat peningkatan usaha. Informan juga menganggap pelatihan kewirausahaan yang telah mereka ikuti sangat memberikan gambaran dalam menentukan organisasi usaha yang akan mereka jalankan

\section{KESIMPULAN}

Berdasarkan hasil analisis wawancara yang dilakukan terhadap informan kesimpulan yang dapat dikemukakan antara lain: Materi pelatihan kewirausahaan yang disampaikan sudah sesuai dengan kebutuhan informan/mahasiswa yang menjadi peserta pelatihan kewirausahaan serta memberikan kontribusi yang positif bagi pelaksanaan usaha mahasiswa baik dalam aspek perencanaan, pengorganisasian, pelaksanaan dan evaluasi usaha mahasiswa. Inisiasi dan pelatihan memberikan kontribusi positif terhadap gambaran cara merencanakan usaha yang baik. Terdapat Perbedaan dalam pelaksanaan usaha informan/mahasiswa sebelum dan setelah mengikuti pelatihan kewirausahaan. Pelatihan kewirausahaan dapat memberikan kontribusi yang baik/positif bagi pelaksanaan usaha mahasiswa peserta pelatihan karena membantu dalam menyelesaikan hambatan usaha mahasiswa yang selama ini mendera.

\section{DAFTAR PUSTAKA}

Gholap, S., Kar, A., (2005). Gymnemic acids from Gymnema sylvestre potentially regulates dexamethasone-induced hyperglycemia in mice. Pharmaceutical Biology 43, 192-195. 
Khan, R.M., Miungwana, S.M., 1999. 5-Hydroxylapachol: a cytotoxic agent from Tectona grandis. Phytochemistry 50, 439-442.

Majumdar, M., Nayeem, N., Kamat, J.V., Asad, M.d., 2007. Evaluation of Tectona grandisleaves for wound healing activity. Pakistan Journal of Pharmaceutical Sciences 20, 120-124.

Moleong, L. J. (1999). Metodologi penelitian. Bandung: PT. Remaja Rosda Karya.

Pandey, B.L., Goel, R.K., Pathak, N.K.R., Biswas, M., Das, P.K., 1982. Effect of Tectonagrandis Linn. (common teak tree) on experimental ulcers and gastric secretion.Indian Journal of Medicinal Research 76 (Suppl.), 89-94.

Sumthong, P., Damveld, R.A., Choi, Y.H., Arentshorst, M., Ram, A.F.J., Van den Hondel, C.A.M.J.J., Verpoorte, R., 2006. Activity of Quinones from teak (Tectona grandis) on fungal cell wall stress. Planta Medica 72, 943944.

Timmons, J., \& Spinelli, S. (2004). New venture strategies: Entrepreneurship for the $21^{\text {st }}$ century. Burr Ridge, IL: Irwin-McGraw-Hill Publishers.

Warrier, P.S., 1994. Indian Medicinal Plants, 1st ed. Orient Longman Private Limited,New Delhi, pp. 245-248. 
